\title{
Marine Fish Proteins and Peptides for Cosmeceuticals: A Review
}

\author{
Jayachandran Venkatesan ${ }^{1}$, Sukumaran Anil ${ }^{2}$, Se-Kwon Kim ${ }^{3, *}$ and Min Suk Shim ${ }^{1, *}$ \\ 1 Division of Bioengineering, Incheon National University, Incheon 406-772, Korea; venkatjchem@gmail.com \\ 2 Department of Preventive Dental Sciences, College of Dentistry, Prince Sattam Bin Abdulaziz University, \\ Riyadh, Post Box 153, AIKharj 11942, Saudi Arabia; drsanil@gmail.com \\ 3 Department of Marine Life Sciences, Korean Maritime and Ocean University, 727 Taejong-ro, \\ Yeongdo-Gu, Busan 49112, Korea \\ * Correspondence: sknkim@pknu.ac.kr (S.-K.K.); msshim@inu.ac.kr (M.S.S.); \\ Tel.: +82-51-629-7550 (S.-K.K.); +82-32-835-8268 (M.S.S.)
}

Academic Editor: Orazio Taglialatela-Scafati

Received: 28 February 2017; Accepted: 11 May 2017; Published: 18 May 2017

\begin{abstract}
Marine fish provide a rich source of bioactive compounds such as proteins and peptides. The bioactive proteins and peptides derived from marine fish have gained enormous interest in nutraceutical, pharmaceutical, and cosmeceutical industries due to their broad spectrum of bioactivities, including antioxidant, antimicrobial, and anti-aging activities. Recently, the development of cosmeceuticals using marine fish-derived proteins and peptides obtained from chemical or enzymatical hydrolysis of fish processing by-products has increased rapidly owing to their activities in antioxidation and tissue regeneration. Marine fish-derived collagen has been utilized for the development of cosmeceutical products due to its abilities in skin repair and tissue regeneration. Marine fish-derived peptides have also been utilized for various cosmeceutical applications due to their antioxidant, antimicrobial, and matrix metalloproteinase inhibitory activities. In addition, marine fish-derived proteins and hydrolysates demonstrated efficient anti-photoaging activity. The present review highlights and presents an overview of the current status of the isolation and applications of marine fish-derived proteins and peptides. This review also demonstrates that marine fish-derived proteins and peptides have high potential for biocompatible and effective cosmeceuticals.
\end{abstract}

Keywords: marine fish; cosmeceuticals; proteins; peptides; hydrolysates; collagen; antioxidant; anti-photoaging

\section{Introduction}

Oceans cover about $70 \%$ of the earth's surface and are inhabited by a large variety of living organisms. The marine environment serves as an enormous resource that provides abundant bioactive substances in the form of food, cosmeceuticals, and pharmaceutical products. Recently, much attention has been paid to obtaining bioactive proteins and peptides from various marine organisms, including fish, algae, crustaceans, and sponges, for cosmeceutical and pharmaceutical applications [1,2]. Marine bioactive proteins and peptides, depending on their structures and amino acid sequences, exhibit a wide range of biological activities including antioxidant, antimicrobial, anticancer, immunomodulatory, antihypertensive, anticoagulant, and anti-diabetic effects $[3,4]$.

Marine fish is mostly used as a source of food for human consumption, which has resulted in several fish processing industries producing fish meat. However, these industries discard huge amounts of waste containing fish skin and bones, which in turn aggravate the problem of environmental pollution. To avoid such issues, by-products generated by seafood processing industries are utilized to 
isolate bioactive compounds beneficial for human health. This process not only assists in decreasing the pollution but also increases the value of the by-products from fish processing [5-7]. Fish processing waste contains significant amounts of useful proteins, which represent a source for bioactive peptide mining. For example, collagen is one of the most abundant proteins that can be extracted from the skin, bones, and scales of fish. Collagen has been extensively utilized for various applications, including cosmeceuticals [8], functional foods [9], tissue engineering [10,11], and anti-diabetic medications [12].

In addition to bioactive proteins, various bioactive peptides can be produced from marine fish via chemical or enzymatical hydrolysis. The peptides, which are present in the inactive form within the protein chains, are activated after their hydrolysis using enzymes, including trypsin, proteinases, chymotrypsin, alcalase, and pepsin [3,13-15]. Marine fish waste-derived bioactive peptides have gained tremendous interest in nutraceutical and cosmeceutical industries due to their broad spectrum of bioactivities, including antioxidant, antimicrobial, antihypertensive, calcium-binding, and obesity control properties $[3,16]$. This review describes various bioactive proteins and peptides, which were identified in marine processing waste with emphasis on their potential bioactivities for cosmeceutical applications. Moreover, it outlines current technologies used in the production and purification of the marine fish-derived proteins and peptides.

\section{Marine Fish Proteins and Peptides}

Figure 1 depicts the increasing number of the studies on marine fish-derived proteins and peptides in the last two decades. Marine fish proteins mainly consist of collagen, which has been widely utilized in cosmeceutical areas owing to its moisturizing properties. In addition, it has been extensively studied in pharmaceuticals, nutraceuticals, and food applications. Collagen can be isolated from by-products of fish processing, such as fish bones and fish skin [17-19].

\section{(A)}

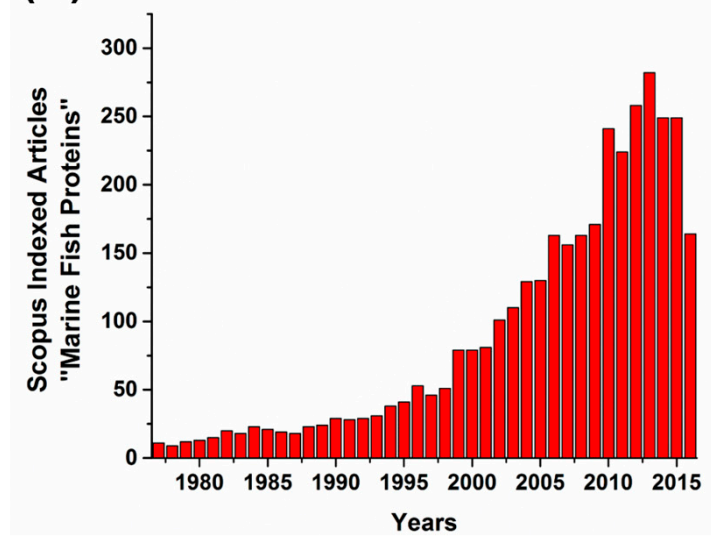

(B)

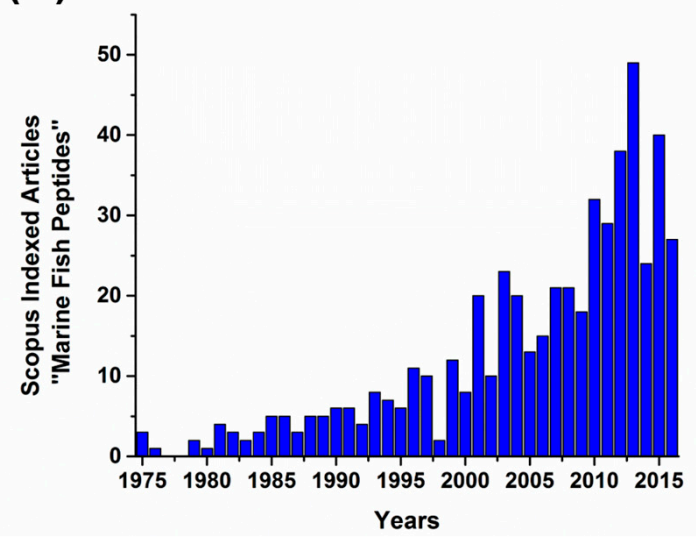

Figure 1. Articles indexed in Scopus with the keywords (A) marine fish proteins and (B) marine fish peptides. Graph shows the continuous research growth on marine fish proteins and peptides. The bar graph highlights the number of articles indexed in Scopus on "marine fish proteins", which is greater than that of "marine fish peptides".

\section{Marine Fish-Derived Collagen}

Collagen is a main structural protein in connective tissues of skin and bone. It is commonly obtained from bovine and porcine skin. The bovine and porcine collagens have been extensively used for pharmaceutical, cosmeceutical, and nutraceutical purposes. However, the outbreak of certain transmissible diseases such as bovine spongiform encephalopathy and some religious issues associated with the use of bovine proteins hamper their use. Hence, there has been a need to find a suitable alternative to solve these issues, which has led several researchers to turn toward marine sources for the production of collagen. Marine-derived collagen has an ability to scavenge free radicals, and thus 
can be utilized for skin care products $[17,20,21]$. Marine-derived collagen has also been widely used as a scaffold for tissue engineering due to its excellent bioactive properties, including biocompatibility, low antigenicity, high biodegradability, and cell growth potential [22-24]. There are two types of collagen: fibrillar and nonfibrillar. Marine fish often contain Type I fibrillar collagen in skin and bones [25].

\subsection{Isolation of Marine Fish-Derived Collagen}

Although around $75 \%$ of the fish weight consists of skin, bones, head, and scales, they are often discarded as by-products by the seafood processing industries [26]. These by-products are a rich source of collagen with a variety of bioactivities. Figure 2 shows the common procedures for isolating collagen from the skin and bones of marine fish $[19,26,27]$. Acid solubilization and pepsin solubilization are major methods for isolating collagen from various parts of fish species (e.g., skin, bones, and scales). For the acid-soluble collagen (ASC) method, $0.5 \mathrm{M}$ acetic acid is used to digest the fish skin in sufficient time, whereas $10 \% w / v$ pepsin is used for the pepsin-soluble collagen (PSC) method. Table 1 shows a list of some important marine fish species used for collagen isolation. It is observed that the PSC method leads to higher amounts of collagen as compared to the ASC method [19,27,28]. This implies that pepsin in the PSC method is more efficient in digesting skin or bone tissues as compared to acid solution in the ASC method.

\section{(A) Acid soluble collagen method}

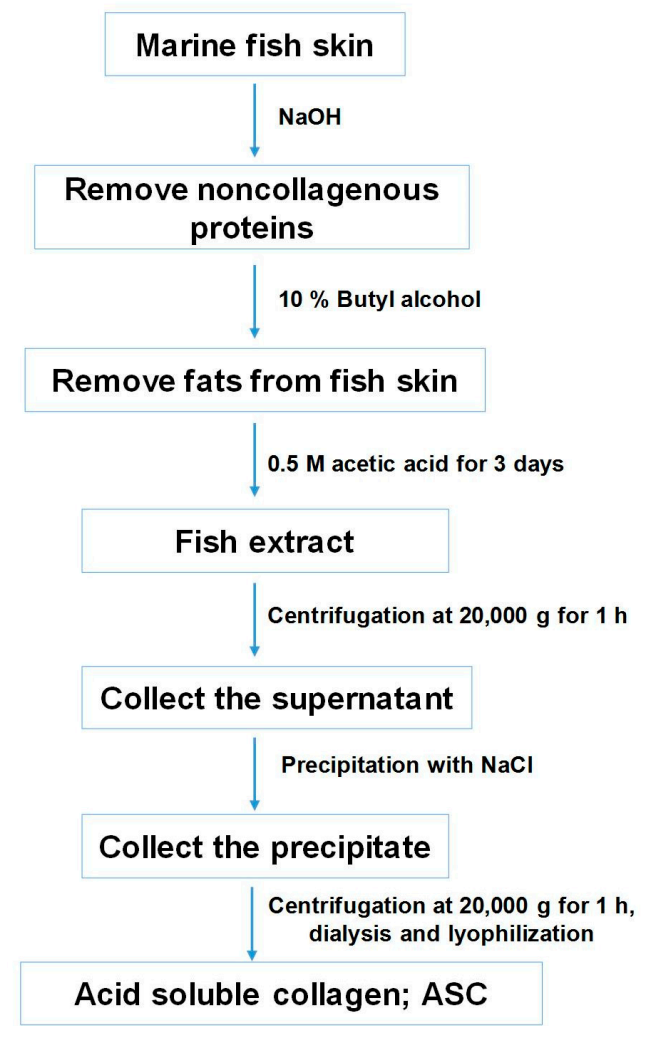

(B) Pepsin soluble collagen method

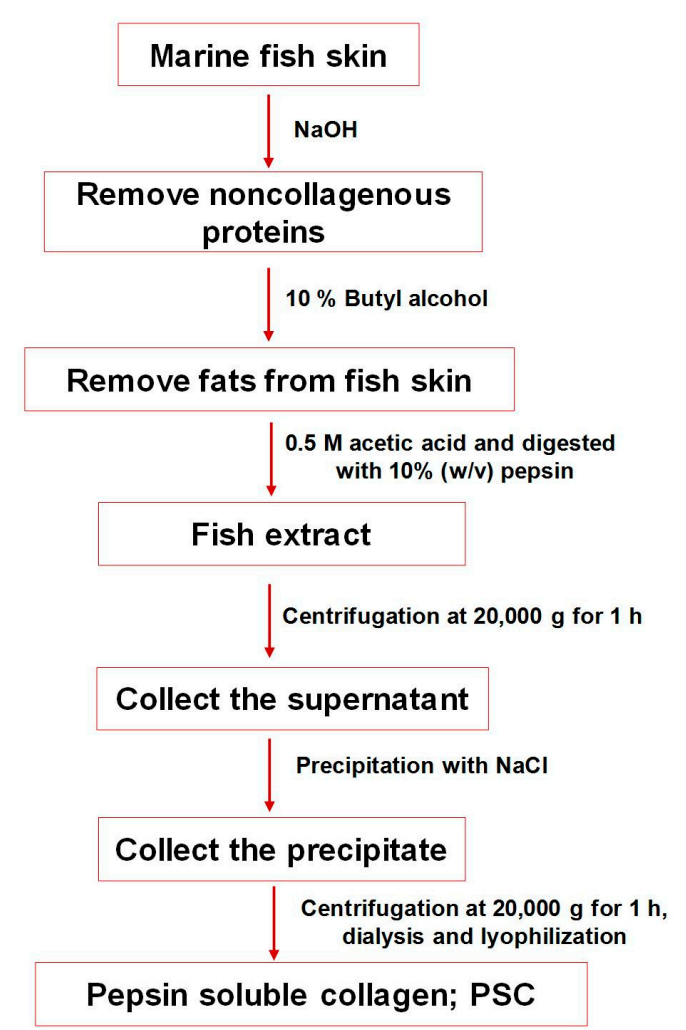

Figure 2. A flowchart for the isolation of collagen from marine fish skin. (A) acid-soluble collagen (ASC) method and (B) pepsin-soluble collagen (PSC) method. 
Table 1. Important marine fish species used to isolate collagen.

\begin{tabular}{ccccc}
\hline Fish Species Name & Parts & Method & Yield (\%) & Reference \\
\hline Lagocephalus gloveri & Skin & PSC & 54.3 & {$[17]$} \\
Thunnus obesus & Bone & ASC and PSC & - & {$[19]$} \\
Paralichthys olivaceus, Sebastes schlegeli, & Skin & ASC & - & {$[22]$} \\
Lateolabrax maculatus, Pagrus major & Skin & ASC and PSC & 10.7 and 44.7 & {$[27]$} \\
Takifugu rubripes & Skin & ASC and PSC & 0.58 and 16.23 & {$[28]$} \\
Sepiella inermis & Skin & ASC and PSC & 9.0 and 4.7 & {$[29]$} \\
Lutjanus vitta & Bone & ASC and PSC & 30.5 and 27.6 & {$[30]$} \\
Magalaspis cordyla & Bone & ASC and PSC & 45.1 and 48.6 & {$[30]$} \\
Otolithes ruber & Skin & ASC and PSC & 80 and 7.1 & {$[31,32]$} \\
Evenchelys macrura & Scales & ASC & $0.13-1.5 \%$ & {$[33]$} \\
Saurida spp., Trachurus japonicus, Mugil cephalis, & All parts & ASC and PSC & 13.0 and 5.5 & {$[34]$} \\
Cypselurus melanurus, Dentex tumifrons & Scales & ASC and PSC & 1.25 and 3 & {$[35]$} \\
Cyanea nozakii Kishinouye & Akind and bone & ASC & 10.94 and 1.59 & {$[36]$} \\
Sardinella longiceps & Skin & PSC & - & {$[37]$} \\
Priacanthus tayenus & Skin & PSC & - & {$[38]$} \\
Priacanthus tayenus & Scale & ASC and PSC & 0.46 and 1.2 & {$[39]$} \\
mriacanthus tayenus and Priacanthus & Skin & ASC and PSC & 16.8 and 28 & {$[40]$} \\
Parupeneus heptacanthus & All parts & ASC and PSC & 5.5 and 33.2 & {$[41]$} \\
Mystus macropterus & All parts & PSC & 46.4 & {$[42]$} \\
Syngnathus schlegeli & All parts & PSC & $9-19$ & {$[43]$} \\
Jellyfish & & &
\end{tabular}

\subsection{Marine Fish-Derived Collagen in Cosmeceuticals}

Marine fish-derived collagen is extensively employed in the development of cosmeceutical products due to its excellent bioactivity toward skin repair and regeneration. The marine fish-derived collagen possesses a higher absorbing capacity than the collagen from animal sources [44]. In addition, marine fish-derived collagen has low odor and improved mechanical strength, prerequisites for cosmetic products [8]. Skin-hydrating and skin-firming effects of cosmetic formulations (cream or serum formulations) using collagen derived from fish were evaluated [45]. The result suggested that serum formulations displayed a better moisturizing effect within a short duration $[44,45]$. The cream formulations appeared to become more active later, particularly following the repetitive applications. However, a sustained tensor (firming) effect was observed during the treatment using both the lotion and the cream [45].

\subsection{Marine Fish-Derived Collagen in Wound Healing and Tissue Engineering}

Tissue-engineered skin substitutes serve as a promising therapeutic agent in replacing the skin lost in wounds such as burns by providing cells, bioactive compounds, bioactive polymers, and proper microenvironments, thereby initiating the wound healing process [46-48]. Currently, a main source of collagen is bovine skin and tendons as well as porcine skin, which suffer from drawbacks such as transmission of prions [49]. Therefore, marine organism-derived materials have become initiators or co-initiators of hundreds of promising pharmaceutical and tissue-engineered skin substitutes [50]. Many studies based on marine organism-derived collagen scaffolds for skin tissue regeneration have demonstrated a high potential in clinical applications [51]. In this regard, a composite film comprising salmon milt DNA and salmon collagen showed a remarkable efficacy in wound regeneration [52]. The implantation of the film into a full-thickness wound in the rat dorsal region resulted in tissue regeneration with a morphological appearance similar to that of native rat dermis tissues. In addition, it significantly enhanced the formation of blood capillaries [52].

The abundant presence of type I collagen in fish bone tissues has widely increased the applications of collagen-based scaffolds for bone tissue engineering [53-55]. Collagen plays an important role in stimulating the differentiation of bone progenitor cells into osteoblasts through interaction 
with transmembrane $\alpha 2 \beta 1$ integrin receptors, and subsequently eliciting cell growth and mineral production [56,57]. The incorporation of glycosaminoglycans (GAGs) into collagen has shown to enhance osteoblastic differentiation of mesenchymal stem cells (MSCs) both in vivo and in vitro [58,59].

\section{Marine Fish-Derived Peptides}

Marine fish proteins consist of small peptides, which are often present in the inactive form with a full protein sequence. Enzymatic hydrolysis is frequently used to isolate short and bioactive peptides from marine organisms and seafood waste products. A large amount of histidine-containing dipeptides, carnosine ( $\beta$-alanylhistidine), and anserine ( $\beta$-alanyl-1-methylhistidine) are present in tuna, salmon, and eels [60]. Peptides serve as important active ingredients for several pharmaceutical and cosmeceutical applications $[4,61,62]$. The bioactive peptides are usually made up of 3-20 amino acid residues. Marine fish-derived peptides exhibit various biological activities such as antioxidant, antimicrobial, and angiotensin-I-converting inhibitory activity, as well as cancer metastasis inhibition, and immunostimulant activity [63-65]. The most commonly used proteinases for the hydrolysis of fish proteins include alcalase, chymotrypsin, and pepsin [66-68].

\subsection{Isolation of Marine Fish Peptides}

Enzymatic hydrolysis is one of the commonly used methods to obtain bioactive peptides. The mechanistic study of the enzymatic hydrolysis of fish proteins is described elsewhere [69]. The general procedures to produce collagen peptides from marine fish skin and bone are shown in Figure 3. Various antioxidant marine fish-derived peptides were obtained through enzymatic hydrolysis methods [70,71]. Different kinds of enzymes (e.g., alcalase, $\alpha$-chymotrypsin, neutrase, papain, pepsin, and trypsin) were used for the optimized conditional buffer system (Table 2) [70]. The peptides are commonly separated using chromatographic techniques and ultrafiltration membranes. The same group also reported the use of a series of ultrafiltration membranes to separate the peptides [72]. Fast protein liquid chromatography (FPLC) and reverse phase high-pressure liquid chromatography (RP-HPLC) were widely utilized to purify the peptides.

\section{Procedures for the isolation of marine fish peptides}

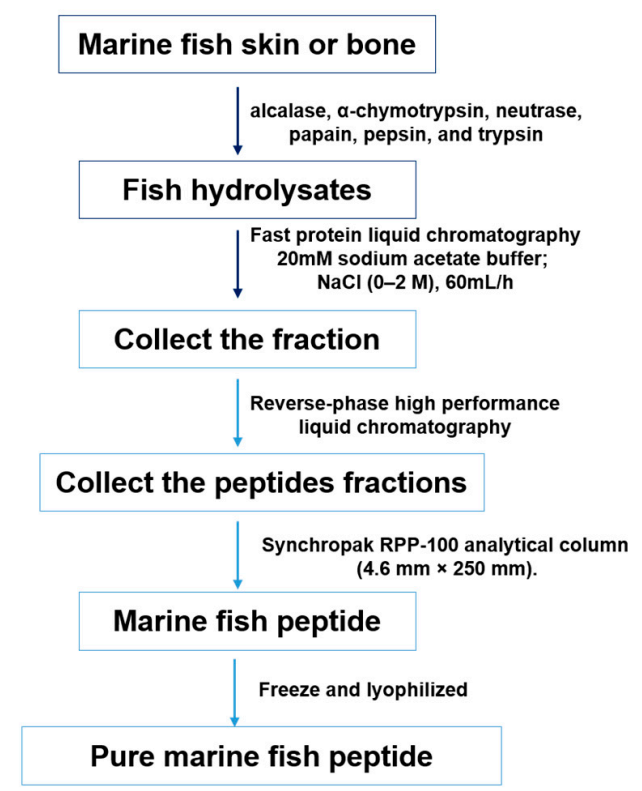

Figure 3. The flowchart showing the common procedures for the isolation and identification of the marine fish-derived peptides through enzymatic hydrolysis methods [70]. 
Table 2. Conditions for the enzymatic hydrolysis of tuna backbone proteins.

\begin{tabular}{|c|c|c|c|}
\hline Enzymes for Hydrolysis & Buffer & $\mathrm{pH}$ & Temperature $\left({ }^{\circ} \mathrm{C}\right)$ \\
\hline alcalase & $0.1 \mathrm{M} \mathrm{Na}_{2} \mathrm{HPO}_{4}-\mathrm{NaH}_{2} \mathrm{PO}_{4}$ & 7 & 50 \\
\hline$\alpha$-chymotrypsin & $0.1 \mathrm{M} \mathrm{Na}_{2} \mathrm{HPO}_{4}-\mathrm{NaH}_{2} \mathrm{PO}_{4}$ & 8 & 37 \\
\hline papain & $0.1 \mathrm{M} \mathrm{Na}_{2} \mathrm{HPO}_{4}-\mathrm{NaH}_{2} \mathrm{PO}_{4}$ & 6 & 37 \\
\hline pepsin & $0.1 \mathrm{M}$ Glycine- $\mathrm{HCl}$ & 2 & 37 \\
\hline neutrase & $0.1 \mathrm{M} \mathrm{Na}_{2} \mathrm{HPO}_{4}-\mathrm{NaH}_{2} \mathrm{PO}_{4}$ & 8 & 50 \\
\hline trypsin & $0.1 \mathrm{M} \mathrm{Na}_{2} \mathrm{HPO}_{4}-\mathrm{NaH}_{2} \mathrm{PO}_{4}$ & 8 & 37 \\
\hline
\end{tabular}

\subsection{Biological Activities of Marine Fish Peptides as Cosmeceuticals}

An increasing interest in health, well-being, and physical appearance has resulted in high demand for various cosmetics. Recently, a combination of cosmetics with pharmaceuticals and marine-derived biologically active ingredients has become the hallmark of cosmetic industries [15,73-76]. Antioxidant, anti-inflammatory, reduction of melanin synthesis, tyrosinase inhibition, and matrix metalloproteinase (MMP) inhibitor tests are important in the development of cosmeceuticals against aging and wrinkling of the skin (Table 3).

Table 3. Biological activities for cosmeceutical applications. MMP: matrix metalloproteinase.

\begin{tabular}{ccc}
\hline Activity & Cosmeceutical Applications & Reference \\
\hline Antioxidant & Anti-aging, photo-protective effects & {$[15]$} \\
Tyrosinase inhibitor & Whitening & {$[75]$} \\
MMP inhibitor & Anti-wrinkle & {$[76]$} \\
Anti-inflammatory & Skin soothing & {$[77]$} \\
\hline
\end{tabular}

\subsection{Antioxidant Fish Peptides}

Antioxidants play an important role in providing protection against oxidative stress. The generation of oxidative stress is attributed to the formation of several reactive oxygen species, including alkyl radicals, hydroxyl radicals, superoxide radicals, peroxide radicals, and singlet oxygen species. In the human body, an imbalance between the free radicals and antioxidants leads to skin damage, inflammation, cancer, and neuron-related diseases [78]. The highly reactive free radicals can easily damage cellular membranes, DNA, proteins, and lipids, and are widely accepted as the primary reason for skin aging [79]. The human body possesses various antioxidant enzymes (e.g., catalase, superoxide dismutase, and glutathione peroxidase) and biomolecules (e.g., vitamin C, vitamin glutathione, and ubiquinone) to control the free radicals inside [79]. In addition, several synthetic products are often used to inhibit free radical activity (e.g., butylated hydroxyanisole (BHA), butylated hydroxytoluene (BHT), tert-butylhydroquinone (TBHQ), and propyl gallate [80]). However, the major drawback of using these antioxidants is the safety concern. Therefore, considerable attention has been diverted to the use of naturally-derived antioxidants [81-85]. Recently, a number of studies have demonstrated that various peptides derived from marine fish serve as effective antioxidants (Table 4) [71,86-98]. Enzymes for the isolation of antioxidant peptides from the marine fish are also described in Table 4.

Various types of methods have been used to evaluate the antioxidant activity of fish-derived peptides, including the 2,2-diphenyl-1-picrylhydrazyl (DPPH) radical scavenging assay, the 2,2'-azino-bis(3-ethylbenzothiazoline-6-sulphonic acid) (ABTS) radical scavenging assay, hydroxyl radical scavenging activity, $\mathrm{Cu}^{2+}$ chelating activity, and $\mathrm{Fe}^{2+}$ chelating activity [99-105]. 
Table 4. Potential bioactive antioxidant peptides from marine fish resources.

\begin{tabular}{|c|c|c|c|}
\hline Fish Species Name & Enzymes for Hydrolysis & Peptides (Amino Acid Sequence) & Reference \\
\hline Scomber austriasicus & protease $\mathrm{N}$ & - & [60] \\
\hline Thunnus obesus & $\begin{array}{l}\text { alcalase, } \alpha \text {-chymotrypsin, neutrase, papain, } \\
\text { pepsin, and trypsin }\end{array}$ & $\begin{array}{l}\text { H-Leu-Asn-Leu-Pro-Thr-Ala-Val-Tyr-Met- } \\
\text { Val-Thr-OH }\end{array}$ & [71] \\
\hline Salmon & $\begin{array}{l}\text { alcalase, flavourzyme, neutrase, pepsin, } \\
\text { protamex, and trypsin }\end{array}$ & Peptides (unknown sequence, 1000-2000 Da) & [86] \\
\hline Decapterus maruadsi & $\begin{array}{l}\text { alcalase, neutral protease, papain, pepsin, } \\
\text { and trypsin }\end{array}$ & $\begin{array}{l}\text { His-Asp-His-Pro-Val-Cys and } \\
\text { His-Glu-Lys-Val-Cys }\end{array}$ & [87] \\
\hline Johnius belengerii & $\begin{array}{l}\text { pepsin, trypsin, papain, } \alpha \text {-chymotrypsin, } \\
\text { alcalase, and neutrase }\end{array}$ & $\begin{array}{l}\text { Glu-Ser-Thr-Val-Pro-Glu-Arg-Thr-His-Pro- } \\
\text { Ala-Cys-Pro-Asp-Phe-Asn }\end{array}$ & [88] \\
\hline Paralichthys olivaceus & $\begin{array}{l}\text { papain, pepsin, trypsin, neutrase, alcalase, } \\
\text { kojizyme, protamex, and } \alpha \text {-chymotrypsin }\end{array}$ & Val-Cys-Ser-Val and Cys-Ala-Ala-Pro & [89] \\
\hline Magalaspis cordyla & pepsin, trypsin, and $\alpha$-chymotrypsin & Ala-Cys-Phe-Leu (518.5 Da), & [90] \\
\hline Magalaspis cordyla & pepsin/trypsin, and $\alpha$-chymotrypsin & Asn-His-Arg-Tyr-Asp-Arg (856 Da) & [91] \\
\hline Otolithes ruber & pepsin/trypsin and $\alpha$-chymotrypsin & $\begin{array}{l}\text { Gly-Asn-Arg-Gly-Phe-Ala-Cys-Arg-His-Ala } \\
\text { (1101.5 Da) }\end{array}$ & [91] \\
\hline Johnius belengerii & trypsin, R-chymotrypsin, and pepsin & His-Gly-Pro-Leu-Gly-Pro-Leu & [92] \\
\hline Otolithes ruber & pepsin, trypsin, and $\alpha$-chymotrypsin & Lys-Thr-Phe-Cys-Gly-Arg-His & [93] \\
\hline Oreochromis niloticus & alcalase, pronase E, pepsin, and trypsin & $\begin{array}{l}\text { Asp-Pro-Ala-Leu-Ala-Thr-Glu-Pro-Asp-Pro- } \\
\text { Met-Pro-Phe }\end{array}$ & [94] \\
\hline Merluccius productus & Validase ${ }^{\circledR}$ BNP $(\mathrm{V})$ and Flavourzyme ${ }^{\circledR}$ & - & [95] \\
\hline Oreochromis niloticus & properase $\mathrm{E}$ and multifect neutral & $\begin{array}{l}\text { Glu-Gly-Leu ( } 317.33 \mathrm{Da}) \text { and } \\
\text { Tyr-Gly-Asp-Glu-Tyr }\end{array}$ & [96] \\
\hline Hypoptychus dybowskii & $\begin{array}{l}\text { alcalase, neutrase, } \alpha \text {-chymotrypsin, papain, } \\
\text { pepsin, and trypsin }\end{array}$ & Ile-Val-Gly-Gly-Phe-Pro-His-Tyr-Leu & {$[97]$} \\
\hline
\end{tabular}

\subsection{Antimicrobial Fish Peptides}

Antimicrobial peptides possess cationic moieties, which facilitate their interaction with membranes of microbial pathogens [106]. Antimicrobial peptides from marine organisms constitute a new generation of antibiotics. They are currently extensively studied in the development of cosmeceutical products, including lotions, shampoos, and moisture creams. Numerous studies have reported that marine fish-derived peptides can be used as antimicrobial agents, as shown in Table 5 [103-106]. The enzymes used for the isolation of antimicrobial fish peptides and the microorganisms susceptible to these antimicrobial peptides were listed in Table 5.

Table 5. Marine fish species and enzymes used in the isolation of antimicrobial peptides. Targeted microorganisms used to check the marine fish-derived antimicrobial peptides are shown.

\begin{tabular}{cllc}
\hline Name of Fish Species & \multicolumn{1}{c}{ Enzymes for Hydrolysis } & \multicolumn{1}{c}{ Microorganisms } & Reference \\
\hline Setipinna taty & pepsin & Escherichia coli & [107] \\
\hline Setipinna taty & $\begin{array}{l}\text { papain, pepsin, trypsin, } \\
\text { alkaline protease, acidic protease, } \\
\text { and flavoring protease }\end{array}$ & $\begin{array}{l}\text { Escherichia coli, Pseudomonas fluorescens } \\
\text { Proteus vulgaris, Bacillus megaterium } \\
\text { Staphylococcus aureus, Bacillus subtilis, } \\
\text { Bacillus megaterium, Sarcina lutea }\end{array}$ & {$[108]$} \\
\hline Scomber scombrus & - & Listeria innocua, Escherichia coli & {$[109]$} \\
\hline Scomber scombrus & $\begin{array}{l}\text { protamex, neutrase, papain, } \\
\text { and flavourzyme. }\end{array}$ & Listeria innocua HPB13 and Escherichia coli & {$[110]$} \\
\hline
\end{tabular}

\subsection{Matrix Metalloproteinases Inhibiting Fish Peptides}

MMPs are endopeptidases containing zinc metal ion with an ability to degrade extracellular components. MMPs are produced by a variety of cells, including fibroblasts, keratinocytes, mast cells, macrophages, and neutrophils. Six different kinds of MMPs are available, which consist of collagenases, gelatinases, stromelysins, matrilysins, membrane-type MMPs, and other MMPs. The MMPs are 
categorized into three major functional groups. They include interstitial collagenases with affinities toward collagen types I, II, and III, (MMP-1, -8 , and -13 , respectively), stromelysins with specificity for laminin, fibronectin, and proteoglycans (MMP-3, -10, and -11, respectively), and gelatinases that effectively cleave type IV and V collagens (MMP-2 and -9) [67].

Wrinkles are a typical symptom of skin aging, and are associated with the reduction in the amount of collagen that dominates the elasticity of the skin dermal tissues. Since collagen fibers and other extracellular matrix are readily degraded by MMPs, formation of wrinkles is closely associated with increased expression of MMPs throughout the skin aging. Therefore, a variety of MMP inhibitors have been utilized to prevent the formation of wrinkles. However, studies on the use of fish-derived hydrolysates, proteins, and peptides as MMP inhibitors and their applications for cosmeceuticals are limited. Only a few studies focus on the MMP inhibitory activity of marine fish-derived peptides. Ryu et al. reported the isolation of novel peptides from seahorses that effectively increased collagen release through the suppression of collagenases 1 and 3 [111]. The same group isolated a protein from seahorse with an ability to inhibit MMP-1, MMP-3, and MMP-13 [112]. Shen et al. reported the hydrolysis of fish muscle from Collichthys niveatus using four commercial enzymes, namely alcalase, neutrase, protamex, and flavourzyme to isolate the peptides [113]. The major amino acids observed in the hydrolysate were threonine, glutamic acid, phenylalanine, tryptophan, and lysine. The total content of essential amino acids was calculated to be $970.7 \mathrm{ng} / \mathrm{mL}$. The study was performed to check the effects of enzymatic hydrolysis conditions on the composition and properties of the peptides obtained from the hydrolysate, which could be utilized as health supplements [113]. A proteinase inhibitor $(21 \mathrm{kDa})$ with similar properties to human tissue inhibitor of MMP-2 (TIMP-2) was obtained from Atlantic cod muscle and then identified by using gelatin affinity chromatography, real-time reverse zymography, and mass spectroscopy [114]. The amino acid sequences of the two peptides obtained from the inhibitor showed a high similarity to those of the human TIMP-2. The inhibitor was found to inhibit the gelatin-degrading enzymes.

\section{Photo-Protective and Anti-Photoaging Activity of Fish Peptides and Fish Protein Hydrolysates}

Skin is made up of three different layers, namely epidermis, dermis, and hypodermis. It acts as a chemical and physical barrier to protect the body against harmful foreign pollutants [115]. Skin can be damaged by various external environmental attacks, including harmful chemicals, ultraviolet (UV) light exposure, and temperature changes [116]. Photoaging and inflammation are often caused by UV radiation. Photoaging, also known as dermatoheliosis, is characterized by changes in the skin due to exposure of UV-A (400 to 320-nm wavelength) and UV-B (320 to 290-nm wavelength) light, which is main light source for photoaging [117]. The UV-A can permeate more deeply into the dermal matrix than UV-B, whereas UV-B is more carcinogenic compared to UV-A [118]. Considerable attention has been given to the utilization of marine fish-derived peptides for skin protection due to an excellent bioactivity, biocompatibility, penetration ability, and skin-repairing ability. Various fish-derived proteins and peptides have been investigated for their usage in the protection of skin from UV exposure [119-121].

Fish skin collagen and hydrolysates demonstrated a high biocompatibility with an ability to provide protection against the detrimental effects of UV radiation (Table 6). Zhuang et al. reported that jellyfish (Rhopilema esculentum) collagen (JC) and jellyfish collagen hydrolysate (JCH) alleviated UV-induced abnormal changes of antioxidant defense systems such as superoxide dismutase and glutathione peroxidase [116]. Both JC and JCH significantly protected the skin lipid and collagen from UV radiation. In addition, the UV-induced changes in the total ceramide and glycosaminoglycans in the skin were recovered, thus maintaining the balance of lipid compositions in the skin. The mechanism is mainly based on the antioxidative properties of the both JC and JCH along with stimulation of skin collagen synthesis. The study indicated that JCH that has lower molecular weights as compared to JC provides a much stronger protection against UV-induced photoaging [116]. The importance of jellyfish collagen on the antioxidant activities is further strengthened by another study that reports 
jellyfish as an abundant source of collagen with a high potential for nutraceutical applications [122]. The effects of JC and JCH on UV-induced skin damage of mice were evaluated by the analysis of skin moisture as well as microscopic analyses of skin and immunity indexes [123]. It was observed that the moisture retention ability of UV-induced mice skin increased upon treatment with JC and JCH. Further histological analysis demonstrated that JC and JCH could repair the endogenous collagen and elastin protein fibers, thus maintaining the natural ratio of type I to type III collagen. The immunity indexes showed that JC and JCH played a pivotal role in enhancing the immunity of photoaging mice in vivo. Again, as mentioned above, JCH exhibited a much higher protective ability than JC [123].

Hou et al. evaluated the effects of collagen polypeptides isolated from cod skin on UV-induced damage to mouse skin [124]. Collagen polypeptide fractions (CP1 (2 kDa $<\mathrm{Mr}<6 \mathrm{kDa})$ and CP2 $(\mathrm{Mr}<2 \mathrm{kDa}))$ were obtained through pepsin digestion and alkaline protease hydrolysis methods. Collagen polypeptides provided good moisture absorption and retention properties, and CP2 was more efficient than $\mathrm{CP} 1$. In vivo studies demonstrated that both of the peptides provided protective effects against UV-induced wrinkle formation and destruction of skin structures (Figure 4). The action mechanisms of the collagen polypeptides mainly involve increasing immunity, decreasing the loss of moisture and lipid, and repairing endogenous collagen and elastin protein fibers [124].

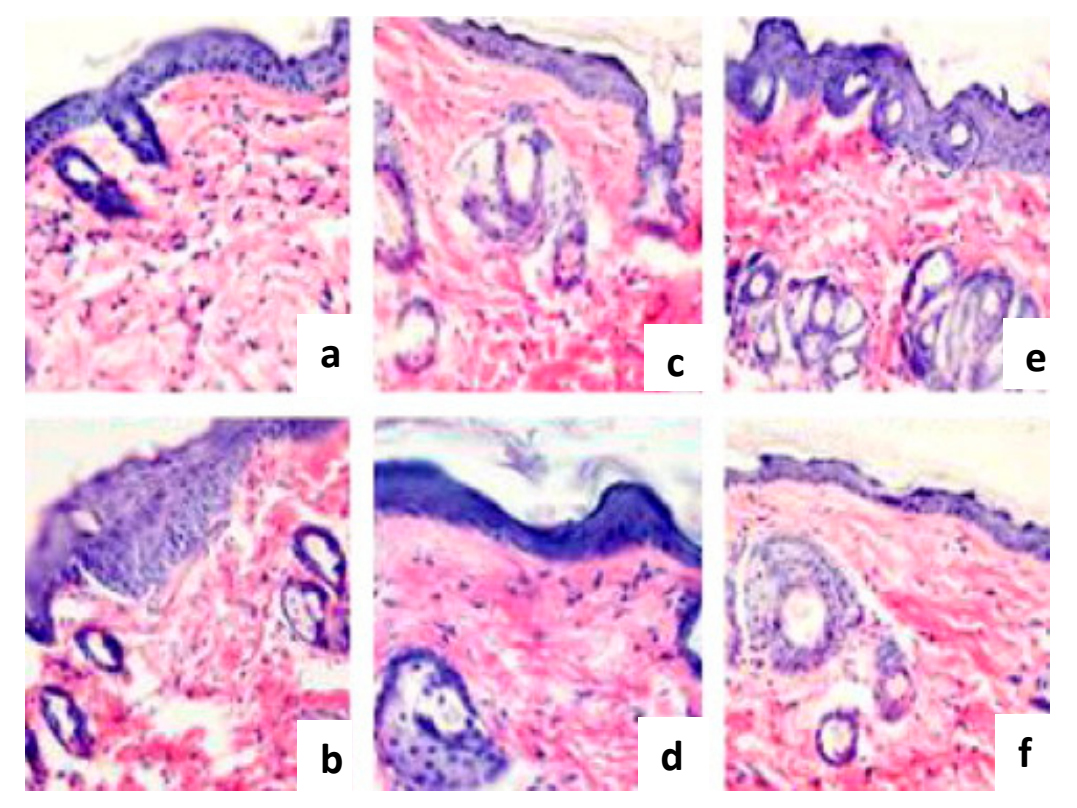

Figure 4. Effects of collagen polypeptide 1 and collagen polypeptide 2 on the morphology of photoaging skin (magnification $200 \times$ ). (a) normal; (b) model; (c) collagen polypeptide 1 (50 mg/kg); (d) collagen polypeptide 1 (200 mg/kg); (e) collagen polypeptide 2 (50 mg/ $\mathrm{kg})$; and (f) collagen polypeptide 2 $(200 \mathrm{mg} / \mathrm{kg})$. Adapted with permission from [124].

Chen et al. studied the effects of gelatin hydrolysate extracted from the Pacific cod (Gadus macrocephalus) skin on UV radiation-induced inflammation and collagen reduction in photoaging mouse skin. Oral administration of gelatin hydrolysate suppressed UV radiation-induced damage to the skin by inhibiting the depletion of endogenous antioxidant enzyme activity, and by suppressing the expression of nuclear factor- $\mathrm{KB}(\mathrm{NF}-\mathrm{kB})$ as well as NF- $\mathrm{kB}$-mediated expression of pro-inflammatory cytokines. Furthermore, gelatin hydrolysate inhibited type I procollagen synthesis by up-regulating the type II transforming growth factor $\beta$ (TGF $\beta$ ) receptor (T $\beta R I I)$ level and down-regulating Smad7 levels, which demonstrates that gelatin hydrolysate is involved in matrix collagen synthesis by activating the TGF- $\beta$ /Smad pathway in the photoaging skin [125].

Age-related skin thinning is involved in a decrease in the content of collagen in the skin. Co-treatment with collagen peptide and vitamin C upregulates the type I collagen in vivo. Shibuya et al. 
demonstrated that the collagen peptides supplemented with vitamin $C$ reduced the superoxide dismutase 1 (Sod-1) [126]. In vitro studies further revealed that collagen oligopeptide, a digestive product of ingested collagen peptide, significantly enhanced the bioactivity of the vitamin C derivative with respect to the migration and proliferation of fibroblasts [126]. The collagen peptide and the vitamin $C$ derivative additively increased the skin thickness of hairless Sod1-deficient mice.

Recently, gelatin and its hydrolysates from salmon skin were used to protect the skin from photoaging [127]. The average molecular weights of the gelatin and gelatin hydrolysates were found to be $65 \mathrm{kDa}$ and $873 \mathrm{kDa}$, respectively [127]. In another study, dose effects of orally administered collagen hydrolysates on the UV-B-irradiated skin damage were investigated using UV-B-irradiated hairless mice [128]. The low dose of collagen hydrolysates increased the skin hydration and reduced the transepidermal water loss in the damaged skin [128]. In addition to this, tilapia gelatin peptides were investigated against UV-induced damage to mouse skin [129]. The results suggested that tilapia gelatin had an ability to avoid the UV damage by protecting the collagen and lipid in the skin. The antioxidant peptide, Leu-Ser-Gly-Tyr-Gly-Pro (592.26 Da), was identified from the tilapia gelatin peptides, and the peptide has an ability to scavenge the hydroxyl radicals with the $\mathrm{IC}_{50}$ value of $22.47 \mu \mathrm{g} / \mathrm{mL}[129,130]$.

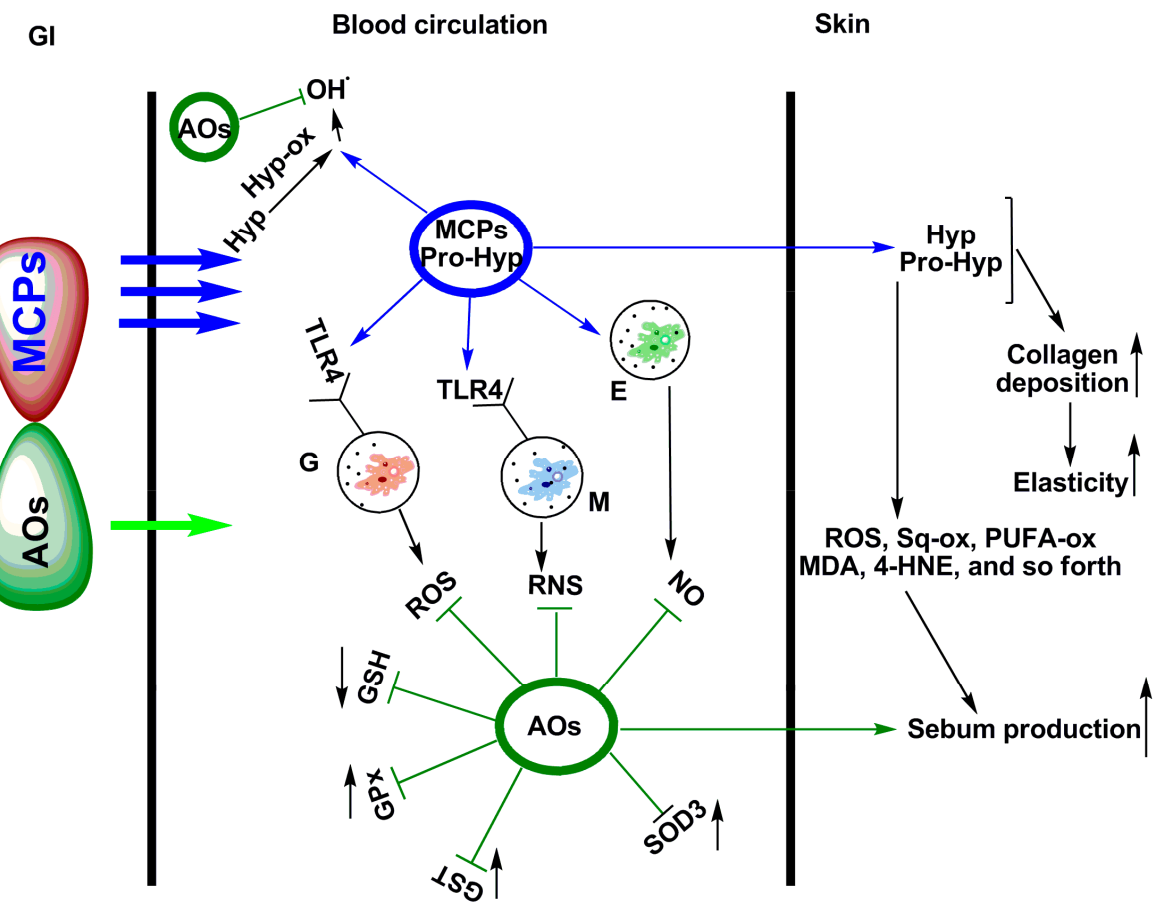

Figure 5. Scheme of the hypothesized redox-dependent mechanisms of physiological effects after co-treatment of marine collagen peptides (MCPs) and skin-targeting antioxidants (AOs). Redrawn with permission from [131]. In the figure, the three arrows (blue) indicate that MCPs easily penetrate the gastrointestinal wall (GI) through blood circulation and are mainly deposited in the skin. The single arrow (green) indicates that AOs are partially metabolized. However, AOs can reach the different layers of skin. While circulating in the blood, MCPs activate blood phagocytes (i.e., granulocytes $(\mathrm{G})$ and monocytes (M)) and endotheliocytes (E) to generate reactive oxygen species (ROS) and reactive nitrogen species (RNS) by provoking Toll-like receptor-4 (TLR4)-mediated signals. Co-administered antioxidants can prevent systemic oxidative stress by blocking glutathione (GSH) oxidation, and activation of glutathione peroxidase (GPx), glutathione-S-transferase (GST), and superoxide dismutase 3 (SOD3).

The major concern regarding the safety and clinical feasibility of administration of marine collagen peptides (MCPs) has been raised because MCPs from different origin can activate innate immune response through Toll-like receptor 4 (TLR4)-mediated NADPH-oxidase (NOX4) activation and over-production of reactive oxygen species (ROS) [131]. Figure 5 represents the 
hypothesized redox-dependent mechanisms behind the physiological effects of fish skin MCPs combined with plant-derived skin-targeting antioxidants (coenzyme Q10 + grape-skin extract + luteolin + selenium) [131]. The MCPs were derived from the skin of deep sea fish (e.g., Pollachius virens, Hippoglossus hippoglossus, and Pleuronectes platessa). MCPs easily penetrate the gastrointestinal (GI) wall (three arrows) through blood circulation and are mainly deposited in the skin [131]. The clinical study demonstrated that combination treatment of MCPs with skin-targeting antioxidants can remarkably improve skin elasticity and sebum production while lowering the oxidative damage [131]. These results clearly indicate that skin-targeting antioxidants are essential components of MCPs-containing cosmeceuticals for more effective and safe treatment.

Table 6. Photo-protective and anti-photoaging proteins and peptides from marine fish.

\begin{tabular}{cccc}
\hline Name of Fish Species and Parts & $\begin{array}{c}\text { Fish-Derived Proteins } \\
\text { and Peptides }\end{array}$ & Enzymes for Hydrolysis & Reference \\
\hline Jellyfish & Collagen & properase E & {$[123]$} \\
Cod skin & Collagen polypeptides & alkaline protease and pepsin & {$[124]$} \\
Cod skin & Gelatin hydrolysate & $\begin{array}{c}\text { alkaline protease and trypsin } \\
\text { alkaline protease and trypsin }\end{array}$ & {$[125]$} \\
Salmon skin & Gelatin & properase E & {$[127]$} \\
Tilapia & Gelatin peptides & complex proteases & {$[131]$} \\
\hline Pippoglossus, and Pleuronectes platessa & Marine collagen peptides & & \\
\hline
\end{tabular}

\section{Conclusions}

Marine fish-derived proteins and peptides are becoming the important resource for cosmetic industries. Several bioactive proteins and peptides were produced from marine fish via chemical or enzymatical hydrolysis and regarded as a safer option for the development of cosmeceutical products. The use of marine fish-derived proteins and peptides contribute to alleviating the environmental pollution caused by the waste generated by fish processing industries. Much attention has been paid to marine fish collagen for cosmeceutical applications owing its properties for skin hydration, with low odor and improved mechanical strength. In addition, marine fish-derived peptides have been extensively explored for cosmeceutical applications due to their various biological properties including antioxidant, antimicrobial, MMP inhibitory, photo-protective, and anti-photoaging activities. These biological activities of the marine fish peptides have led to the development of several types of anti-aging, skin care, and anti-wrinkle products. Despite the great potential of marine fish-derived proteins and peptides for cosmeceutical applications, most of them are still in the experimental stage and need to be further investigated with regard to their formulations and long-term safety for successful commercialization. Moreover, development of supplements that can further increase the bioavailability and tissue regeneration efficacy of marine fish-derived proteins and peptides is also required to increase their potential for cosmeceuticals.

Acknowledgments: This work was supported by the Post-Doctor Research Program (2016) through Incheon National University (INU), Incheon, Republic of Korea. This work was also supported by Basic Science Research Program through the National Research Foundation of Korea (NRF) funded by the Ministry of Education (NRF-2016R1D1A1B03933136 to M.S.S.).

Author Contributions: Jayachandran Venkatesan and Sukumaran Anil developed the concept for the review and wrote the manuscript. Se-Kwon Kim and Min Suk Shim wrote and edited the manuscript.

Conflicts of Interest: The authors declare no conflict of interest.

\section{References}

1. Malve, H. Exploring the ocean for new drug developments: Marine pharmacology. J. Pharm. Bioallied Sci. 2016, 8, 83-91. [CrossRef] [PubMed]

2. Kim, S.-K.; Venkatesan, J. Introduction to marine biotechnology. In Springer Handbook of Marine Biotechnology; Kim, S.-K., Ed.; Springer: Berlin/Heidelberg, Germany, 2015; pp. 1-10. 
3. Najafian, L.; Babji, A.S. A review of fish-derived antioxidant and antimicrobial peptides: Their production, assessment, and applications. Peptides 2012, 33, 178-185. [CrossRef] [PubMed]

4. Cheung, R.C.F.; Ng, T.B.; Wong, J.H. Marine peptides: Bioactivities and applications. Mar. Drugs 2015, 13, 4006-4043. [CrossRef] [PubMed]

5. Senevirathne, M.; Kim, S.-K. Utilization of seafood processing by-products: Medicinal applications. In Advances in Food and Nutrition Research; Kim, S.-K., Ed.; Academic Press: Waltham, MA, USA, 2012; Volume 65, pp. 495-512.

6. Rustad, T. Physical and chemical properties of protein seafood by-products. In Maximising the Value of Marine By-Products; Shahidi, F., Ed.; Woodhead Publishing Limited: Cambridge, UK, 2007; pp. 3-21.

7. Nilsang, S.; Lertsiri, S.; Suphantharika, M.; Assavanig, A. Optimization of enzymatic hydrolysis of fish soluble concentrate by commercial proteases. J. Food Eng. 2005, 70, 571-578. [CrossRef]

8. Allard, R.; Malak, N.A.; Huc, A. Collagen Product Containing Collagen of Marine Origin with a Low Odor and Preferably with Improved Mechanical Properties, and Its Use in the Form of Cosmetic or Pharmaceutical Compositions or Products. U.S. Patent 6,660,280, 9 December 2003.

9. Shahidi, F.; Kamil, Y.J. Enzymes from fish and aquatic invertebrates and their application in the food industry. Trends Food Sci. Technol. 2001, 12, 435-464. [CrossRef]

10. Hoyer, B.; Bernhardt, A.; Heinemann, S.; Stachel, I.; Meyer, M.; Gelinsky, M. Biomimetically mineralized salmon collagen scaffolds for application in bone tissue engineering. Biomacromolecules 2012, 13, 1059-1066. [CrossRef] [PubMed]

11. Hayashi, Y.; Yamada, S.; Guchi, K.Y.; Koyama, Z.; Ikeda, T. Chitosan and fish collagen as biomaterials for regenerative medicine. In Advances in Food and Nutrition Research; Kim, S.K., Ed.; Academic Press: Waltham, MA, USA, 2012; Volume 65, pp. 107-120.

12. Lauritano, C.; Ianora, A. Marine organisms with anti-diabetes properties. Mar. Drugs 2016, 14, 220. [CrossRef] [PubMed]

13. Venugopal, V. Cosmeceuticals from marine fish and shellfish. In Marine Cosmeceuticals: Trends and Prospects; Kim, S.-K., Ed.; CRC Press: Boca Raton, FL, USA, 2011; pp. 211-232.

14. Senevirathne, M.; Kim, S.-K. Development of bioactive peptides from fish proteins and their health promoting ability. In Advances in Food and Nutrition Research; Kim, S.-K., Ed.; Academic Press: Waltham, MA, USA, 2012; Volume 65, pp. 235-248.

15. Ngo, D.H.; Vo, T.S.; Ngo, D.N.; Wijesekara, I.; Kim, S.K. Biological activities and potential health benefits of bioactive peptides derived from marine organisms. Int. J. Biol. Macromol. 2012, 51, 378-383. [CrossRef] [PubMed]

16. Pangestuti, R.; Kim, S.-K. Bioactive peptide of marine origin for the prevention and treatment of non-communicable diseases. Mar. Drugs 2017, 15, 67. [CrossRef] [PubMed]

17. Senaratne, L.; Park, P.-J.; Kim, S.-K. Isolation and characterization of collagen from brown backed toadfish (Lagocephalus gloveri) skin. Bioresour. Technol. 2006, 97, 191-197. [CrossRef] [PubMed]

18. Pati, F.; Adhikari, B.; Dhara, S. Isolation and characterization of fish scale collagen of higher thermal stability. Bioresour. Technol. 2010, 101, 3737-3742. [CrossRef] [PubMed]

19. Jeong, H.-S.; Venkatesan, J.; Kim, S.-K. Isolation and characterization of collagen from marine fish (Thunnus obesus). Biotechnol. Bioprocess Eng. 2013, 18, 1185-1191. [CrossRef]

20. Xu, Y.; Han, X.; Li, Y. Effect of marine collagen peptides on long bone development in growing rats. J. Sci. Food Agric. 2010, 90, 1485-1491. [CrossRef] [PubMed]

21. Swatschek, D.; Schatton, W.; Kellermann, J.; Müller, W.E.; Kreuter, J. Marine sponge collagen: Isolation, characterization and effects on the skin parameters surface-pH, moisture and sebum. Eur. J. Pharm. Biopharm. 2002, 53, 107-113. [CrossRef]

22. Cho, J.K.; Jin, Y.G.; Rha, S.J.; Kim, S.J.; Hwang, J.H. Biochemical characteristics of four marine fish skins in Korea. Food Chem. 2014, 159, 200-207. [CrossRef] [PubMed]

23. Haug, I.J.; Draget, K.I.; Smidsrød, O. Physical and rheological properties of fish gelatin compared to mammalian gelatin. Food Hydrocoll. 2004, 18, 203-213. [CrossRef]

24. Subhan, F.; Ikram, M.; Shehzad, A.; Ghafoor, A. Marine collagen: An emerging player in biomedical applications. J. Food Sci. Technol. 2015, 52, 4703-4707. [CrossRef] [PubMed] 
25. Muralidharan, N.; Jeya Shakila, R.; Sukumar, D.; Jeyasekaran, G. A Skin, bone and muscle collagen extraction from the trash fish, leather jacket (Odonus niger) and their characterization. J. Food Sci. Technol. 2013, 50, 1106-1113. [CrossRef] [PubMed]

26. Silva, T.H.; Moreira-Silva, J.; Marques, A.L.; Domingues, A.; Bayon, Y.; Reis, R.L. Marine origin collagens and its potential applications. Mar. Drugs 2014, 12, 5881-5901. [CrossRef] [PubMed]

27. Nagai, T.; Araki, Y.; Suzuki, N. Collagen of the skin of ocellate puffer fish (Takifugu rubripes). Food Chem. 2002, 78, 173-177. [CrossRef]

28. Shanmugam, V.; Ramasamy, P.; Subhapradha, N.; Sudharsan, S.; Seedevi, P.; Moovendhan, M.; Krishnamoorthy, J.; Shanmugam, A.; Srinivasan, A. Extraction, structural and physical characterization of type I collagen from the outer skin of Sepiella inermis (Orbigny, 1848). Afr. J. Biotechnol. 2012, 11, 14326-14337. [CrossRef]

29. Jongjareonrak, A.; Benjakul, S.; Visessanguan, W.; Nagai, T.; Tanaka, M. Isolation and characterisation of acid and pepsin-solubilised collagens from the skin of Brownstripe red snapper (Lutjanus vitta). Food Chem. 2005, 93, 475-484. [CrossRef]

30. Kumar, N.S.S.; Nazeer, R.A. Wound healing properties of collagen from the bone of two marine fishes. Int. J. Pept. Res. Ther. 2012, 18, 185-192. [CrossRef]

31. Veeruraj, A.; Arumugam, M.; Balasubramanian, T. Isolation and characterization of thermostable collagen from the marine eel-fish (Evenchelys macrura). Process Biochem. 2013, 48, 1592-1602. [CrossRef]

32. Veeruraj, A.; Arumugam, M.; Ajithkumar, T.; Balasubramanian, T. Isolation and characterization of drug delivering potential of type-I collagen from eel fish Evenchelys macrura. J. Mater. Sci. Mater. Med. 2012, 23, 1729-1738. [CrossRef] [PubMed]

33. Minh Thuy, L.T.; Okazaki, E.; Osako, K. Isolation and characterization of acid-soluble collagen from the scales of marine fishes from Japan and Vietnam. Food Chem. 2014, 149, 264-270. [CrossRef] [PubMed]

34. Zhang, J.; Duan, R.; Huang, L.; Song, Y.; Regenstein, J.M. Characterisation of acid-soluble and pepsin-solubilised collagen from jellyfish (Cyanea nozakii Kishinouye). Food Chem. 2014, 150, 22-26. [CrossRef] [PubMed]

35. Muthumari, K.; Anand, M.; Maruthupandy, M. Collagen extract from marine finfish scales as a potential mosquito larvicide. Protein J. 2016, 35, 391-400. [CrossRef] [PubMed]

36. Kittiphattanabawon, P.; Benjakul, S.; Visessanguan, W.; Nagai, T.; Tanaka, M. Characterisation of acid-soluble collagen from skin and bone of bigeye snapper (Priacanthus tayenus). Food Chem. 2005, 89, 363-372. [CrossRef]

37. Nalinanon, S.; Benjakul, S.; Visessanguan, W.; Kishimura, H. Use of pepsin for collagen extraction from the skin of bigeye snapper (Priacanthus tayenus). Food Chem. 2007, 104, 593-601. [CrossRef]

38. Benjakul, S.; Thiansilakul, Y.; Visessanguan, W.; Roytrakul, S.; Kishimura, H.; Prodpran, T.; Meesane, J. Extraction and characterisation of pepsin-solubilised collagens from the skin of bigeye snapper (Priacanthus tayenus and Priacanthus macracanthus). J. Sci. Food Agric. 2010, 90, 132-138. [CrossRef] [PubMed]

39. Matmaroh, K.; Benjakul, S.; Prodpran, T.; Encarnacion, A.B.; Kishimura, H. Characteristics of acid soluble collagen and pepsin soluble collagen from scale of spotted golden goatfish (Parupeneus heptacanthus). Food Chem. 2011, 129, 1179-1186. [CrossRef] [PubMed]

40. Zhang, M.; Liu, W.; Li, G. Isolation and characterisation of collagens from the skin of largefin longbarbel catfish (Mystus macropterus). Food Chem. 2009, 115, 826-831. [CrossRef]

41. Khan, S.B.; Qian, Z.-J.; Ryu, B.; Kim, S.-K. Isolation and biochemical characterization of collagens from seaweed pipefish, Syngnathus schlegeli. Biotechnol. Bioprocess Eng. 2009, 14, 436-442. [CrossRef]

42. Nagai, T.; Ogawa, T.; Nakamura, T.; Ito, T.; Nakagawa, H.; Fujiki, K.; Nakao, M.; Yano, T. Collagen of edible jellyfish exumbrella. J. Sci. Food Agric. 1999, 79, 855-858. [CrossRef]

43. Barzideh, Z.; Latiff, A.A.; Gan, C.Y.; Benjakul, S.; Karim, A.A. Isolation and characterisation of collagen from the ribbon jellyfish (Chrysaora sp.). Int. J. Food Sci. Technol. 2014, 49, 1490-1499. [CrossRef]

44. Available online: https://www.justvitamins.co.uk/blog/bovine-collagen-vs-marine-collagen/ (accessed on 11 May 2017).

45. Xhauflaire-Uhoda, E.; Fontaine, K.; Pierard, G. Kinetics of moisturizing and firming effects of cosmetic formulations. Int. J. Cosmet. Sci. 2008, 30, 131-138. [CrossRef] [PubMed]

46. Chandika, P.; Ko, S.-C.; Oh, G.-W.; Heo, S.-Y.; Nguyen, V.-T.; Jeon, Y.-J.; Lee, B.; Jang, C.H.; Kim, G.; Park, W.S. Fish collagen/alginate/chitooligosaccharides integrated scaffold for skin tissue regeneration application. Int. J. Biol. Macromol. 2015, 81, 504-513. [CrossRef] [PubMed] 
47. Gautam, M.; Purohit, V.; Agarwal, M.; Singh, A.; Goel, R. In vivo healing potential of Aegle marmelos in excision, incision, and dead space wound models. Sci. World J. 2014, 2014, 740197. [CrossRef] [PubMed]

48. Nithya, M.; Suguna, L.; Rose, C. The effect of nerve growth factor on the early responses during the process of wound healing. Biochim. Biophys. Acta Gen. Subj. 2003, 1620, 25-31. [CrossRef]

49. Song, E.; Yeon Kim, S.; Chun, T.; Byun, H.J.; Lee, Y.M. Collagen scaffolds derived from a marine source and their biocompatibility. Biomaterials 2006, 27, 2951-2961. [CrossRef] [PubMed]

50. Yeo, M.; Jung, W.-K.; Kim, G. Fabrication, characterisation and biological activity of phlorotannin-conjugated $\mathrm{PCL} / \beta$-TCP composite scaffolds for bone tissue regeneration. J. Mater. Chem. 2012, 22, 3568-3577. [CrossRef]

51. Hoyer, B.; Bernhardt, A.; Lode, A.; Heinemann, S.; Sewing, J.; Klinger, M.; Notbohm, H.; Gelinsky, M. Jellyfish collagen scaffolds for cartilage tissue engineering. Acta Biomater. 2014, 10, 883-892. [CrossRef] [PubMed]

52. Shen, X.; Nagai, N.; Murata, M.; Nishimura, D.; Sugi, M.; Munekata, M. Development of salmon milt DNA/salmon collagen composite for wound dressing. J. Mater. Sci. Mater. Med. 2008, 19, 3473-3479. [CrossRef] [PubMed]

53. Yamada, S.; Yamamoto, K.; Ikeda, T.; Yanagiguchi, K.; Hayashi, Y. Potency of fish collagen as a scaffold for regenerative medicine. Biomed Res. Int. 2014, 2014, 302932. [CrossRef] [PubMed]

54. Elango, J.; Zhang, J.; Bao, B.; Palaniyandi, K.; Wang, S.; Wenhui, W.; Robinson, J.S. Rheological, biocompatibility and osteogenesis assessment of fish collagen scaffold for bone tissue engineering. Int. J. Biol. Macromol. 2016, 91, 51-59. [CrossRef] [PubMed]

55. Jeong, S.I.; Kim, S.Y.; Cho, S.K.; Chong, M.S.; Kim, K.S.; Kim, H.; Lee, S.B.; Lee, Y.M. Tissue-engineered vascular grafts composed of marine collagen and PLGA fibers using pulsatile perfusion bioreactors. Biomaterials 2007, 28, 1115-1122. [CrossRef] [PubMed]

56. Chen, D.C.; Lai, Y.L.; Lee, S.Y.; Hung, S.L.; Chen, H.L. Osteoblastic response to collagen scaffolds varied in freezing temperature and glutaraldehyde crosslinking. J. Biomed. Mater. Res. 2007, 80, 399-409. [CrossRef] [PubMed]

57. Mullen, C.; Haugh, M.; Schaffler, M.; Majeska, R.; McNamara, L. Osteocyte differentiation is regulated by extracellular matrix stiffness and intercellular separation. J. Mech. Behav. Biomed. 2013, 28, 183-194. [CrossRef] [PubMed]

58. Byrne, E.M.; Farrell, E.; McMahon, L.A.; Haugh, M.G.; O’Brien, F.J.; Campbell, V.A.; Prendergast, P.J.; O'Connell, B.C. Gene expression by marrow stromal cells in a porous collagen-glycosaminoglycan scaffold is affected by pore size and mechanical stimulation. J. Mater. Sci. Mater. Med. 2008, 19, 3455-3463. [CrossRef] [PubMed]

59. Keogh, M.B.; O’Brien, F.J.; Daly, J.S. A novel collagen scaffold supports human osteogenesis-Applications for bone tissue engineering. Cell Tissue Res. 2010, 340, 169-177. [CrossRef] [PubMed]

60. Wu, H.-C.; Chen, H.-M.; Shiau, C.-Y. Free amino acids and peptides as related to antioxidant properties in protein hydrolysates of mackerel (Scomber austriasicus). Food Res. Int. 2003, 36, 949-957. [CrossRef]

61. Kim, S.-K. Marine Proteins and Peptides: Biological Activities and Applications; John Wiley \& Sons: Hoboken, NJ, USA, 2013.

62. Lintner, K.; Peschard, O. Biologically active peptides: From a laboratory bench curiosity to a functional skin care product. Int. J. Cosmet. Sci. 2000, 22, 207-218. [CrossRef] [PubMed]

63. Khora, S.S. Marine fish-derived bioactive peptides and proteins for human therapeutics. Int. J. Pharm. Pharm. Sci. 2013, 5, 31-37.

64. Halim, N.; Yusof, H.; Sarbon, N. Functional and bioactive properties of fish protein hydolysates and peptides: A comprehensive review. Trends Food Sci. Technol. 2016, 51, 24-33. [CrossRef]

65. Sila, A.; Hedhili, K.; Przybylski, R.; Ellouz-Chaabouni, S.; Dhulster, P.; Bougatef, A.; Nedjar-Arroume, N. Antibacterial activity of new peptides from barbel protein hydrolysates and mode of action via a membrane damage mechanism against Listeria monocytogenes. J. Funct. Foods 2014, 11, 322-329. [CrossRef]

66. Kim, S.K. Marine cosmeceuticals. J. Cosmet. Dermatol. 2014, 13, 56-67. [CrossRef] [PubMed]

67. Thomas, N.V.; Kim, S.-K. Beneficial effects of marine algal compounds in cosmeceuticals. Mar. Drugs 2013, 11, 146-164. [CrossRef] [PubMed]

68. Kim, S.-K.; Ravichandran, Y.D.; Khan, S.B.; Kim, Y.T. Prospective of the cosmeceuticals derived from marine organisms. Biotechnol. Bioprocess Eng. 2008, 13, 511-523. [CrossRef]

69. Kristinsson, H.G.; Rasco, B.A. Fish protein hydrolysates: Production, biochemical, and functional properties. Crit. Rev. Food Sci. Nutr. 2000, 40, 43-81. [CrossRef] [PubMed] 
70. Je, J.-Y.; Qian, Z.-J.; Byun, H.-G.; Kim, S.-K. Purification and characterization of an antioxidant peptide obtained from tuna backbone protein by enzymatic hydrolysis. Process Biochem. 2007, 42, 840-846. [CrossRef]

71. Je, J.-Y.; Qian, Z.-J.; Lee, S.-H.; Byun, H.-G.; Kim, S.-K. Purification and antioxidant properties of bigeye tuna (Thunnus obesus) dark muscle peptide on free radical-mediated oxidative systems. J. Med. Food 2008, 11, 629-637. [CrossRef] [PubMed]

72. Jeon, Y.-J.; Byun, H.-G.; Kim, S.-K. Improvement of functional properties of cod frame protein hydrolysates using ultrafiltration membranes. Process Biochem. 1999, 35, 471-478. [CrossRef]

73. Martins, A.; Vieira, H.; Gaspar, H.; Santos, S. Marketed marine natural products in the pharmaceutical and cosmeceutical industries: Tips for success. Mar. Drugs 2014, 12, 1066-1101. [CrossRef] [PubMed]

74. Yoon, N.Y.; Eom, T.-K.; Kim, M.-M.; Kim, S.-K. Inhibitory effect of phlorotannins isolated from Ecklonia cava on mushroom tyrosinase activity and melanin formation in mouse B16F10 melanoma cells. J. Agric. Food Chem. 2009, 57, 4124-4129. [CrossRef] [PubMed]

75. Schurink, M.; van Berkel, W.J.; Wichers, H.J.; Boeriu, C.G. Novel peptides with tyrosinase inhibitory activity. Peptides 2007, 28, 485-495. [CrossRef] [PubMed]

76. Kim, M.-M.; Van Ta, Q.; Mendis, E.; Rajapakse, N.; Jung, W.-K.; Byun, H.-G.; Jeon, Y.-J.; Kim, S.-K. Phlorotannins in Ecklonia cava extract inhibit matrix metalloproteinase activity. Life Sci. 2006, 79, 1436-1443. [CrossRef] [PubMed]

77. Kim, J.-A.; Kim, S.-K. Bioactive peptides from marine sources as potential anti-inflammatory therapeutics. Curr. Protein Pept. Sci. 2013, 14, 177-182. [CrossRef] [PubMed]

78. Birben, E.; Sahiner, U.M.; Sackesen, C.; Erzurum, S.; Kalayci, O. Oxidative stress and antioxidant defense. World Allergy Organ. J. 2012, 5, 9-19. [CrossRef] [PubMed]

79. Rinnerthaler, M.; Bischof, J.; Streubel, M.K.; Trost, A.; Richter, K. Oxidative stress in aging human skin. Biomolecules 2015, 5, 545-589. [CrossRef] [PubMed]

80. Gülçin, İ.; Huyut, Z.; Elmastaş, M.; Aboul-Enein, H.Y. Radical scavenging and antioxidant activity of tannic acid. Arab. J. Chem. 2010, 3, 43-53. [CrossRef]

81. Winata, A.; Lorenz, K. Antioxidant potential of 5-n-pentadecylresorcinol. J. Food Process. Preserv. 1996, 20, 417-429. [CrossRef]

82. Becker, G. Preserving food and health: Antioxidants make functional, nutritious preservatives. Food Process. 1993, 12, 54-56.

83. Osawa, T.; Namiki, M. Natural antioxidants isolated from Eucalyptus leaf waxes. J. Agric. Food Chem. 1985, 33, 777-780. [CrossRef]

84. Byun, H.-G.; Lee, J.K.; Park, H.G.; Jeon, J.-K.; Kim, S.-K. Antioxidant peptides isolated from the marine rotifer, Brachionus rotundiformis. Process Biochem. 2009, 44, 842-846. [CrossRef]

85. Kim, S.-K.; Wijesekara, I. Development and biological activities of marine-derived bioactive peptides: A review. J. Funct. Foods 2010, 2, 1-9. [CrossRef]

86. Ahn, C.-B.; Je, J.-Y.; Cho, Y.-S. Antioxidant and anti-inflammatory peptide fraction from salmon byproduct protein hydrolysates by peptic hydrolysis. Food Res. Int. 2012, 49, 92-98. [CrossRef]

87. Jiang, H.; Tong, T.; Sun, J.; Xu, Y.; Zhao, Z.; Liao, D. Purification and characterization of antioxidative peptides from round scad (Decapterus maruadsi) muscle protein hydrolysate. Food Chem. 2014, 154, 158-163. [CrossRef] [PubMed]

88. Kim, S.-Y.; Je, J.-Y.; Kim, S.-K. Purification and characterization of antioxidant peptide from hoki (Johnius belengerii) frame protein by gastrointestinal digestion. J. Nutr. Biochem. 2007, 18, 31-38. [CrossRef] [PubMed]

89. Ko, J.-Y.; Lee, J.-H.; Samarakoon, K.; Kim, J.-S.; Jeon, Y.-J. Purification and determination of two novel antioxidant peptides from flounder fish (Paralichthys olivaceus) using digestive proteases. Food Chem. Toxicol. 2013, 52, 113-120. [CrossRef] [PubMed]

90. Kumar, N.S.; Nazeer, R.; Jaiganesh, R. Purification and biochemical characterization of antioxidant peptide from horse mackerel (Magalaspis cordyla) viscera protein. Peptides 2011, 32, 1496-1501. [CrossRef] [PubMed]

91. Kumar, N.S.; Nazeer, R.; Jaiganesh, R. Purification and identification of antioxidant peptides from the skin protein hydrolysate of two marine fishes, horse mackerel (Magalaspis cordyla) and croaker (Otolithes ruber). Amino Acids 2012, 42, 1641-1649. [CrossRef] [PubMed] 
92. Mendis, E.; Rajapakse, N.; Kim, S.-K. Antioxidant properties of a radical-scavenging peptide purified from enzymatically prepared fish skin gelatin hydrolysate. J. Agric. Food Chem. 2005, 53, 581-587. [CrossRef] [PubMed]

93. Nazeer, R.; Kumar, N.S.; Ganesh, R.J. In vitro and in vivo studies on the antioxidant activity of fish peptide isolated from the croaker (Otolithes ruber) muscle protein hydrolysate. Peptides 2012, 35, 261-268. [CrossRef] [PubMed]

94. Ngo, D.-H.; Qian, Z.-J.; Ryu, B.; Park, J.W.; Kim, S.-K. In vitro antioxidant activity of a peptide isolated from Nile tilapia (Oreochromis niloticus) scale gelatin in free radical-mediated oxidative systems. J. Funct. Foods 2010, 2, 107-117. [CrossRef]

95. Samaranayaka, A.G.; Li-Chan, E.C. Autolysis-assisted production of fish protein hydrolysates with antioxidant properties from Pacific hake (Merluccius productus). Food Chem. 2008, 107, 768-776. [CrossRef]

96. Zhang, Y.; Duan, X.; Zhuang, Y. Purification and characterization of novel antioxidant peptides from enzymatic hydrolysates of tilapia (Oreochromis niloticus) skin gelatin. Peptides 2012, 38, 13-21. [CrossRef] [PubMed]

97. Lee, W.-S.; Jeon, J.-K.; Byun, H.-G. Characterization of a novel antioxidative peptide from the sand eel Hypoptychus dybowskii. Process Biochem. 2011, 46, 1207-1211. [CrossRef]

98. Kong, Y.-Y.; Chen, S.-S.; Wei, J.-Q.; Chen, Y.-P.; Lan, W.-T.; Yang, Q.-W.; Huang, G.-R. Preparation of antioxidative peptides from spanish mackerel (Scomberomorus niphonius) processing byproducts by enzymatic hydrolysis. Biotechnology 2015, 14, 188-193.

99. Jeevithan, E.; Bao, B.; Zhang, J.; Hong, S.; Wu, W. Purification, characterization and antioxidant properties of low molecular weight collagenous polypeptide $(37 \mathrm{kDa})$ prepared from whale shark cartilage (Rhincodon typus). J. Food Sci. Technol. 2015, 52, 6312-6322. [CrossRef] [PubMed]

100. Gajanan, P.G.; Elavarasan, K.; Shamasundar, B.A. Bioactive and functional properties of protein hydrolysates from fish frame processing waste using plant proteases. Environ. Sci. Pollut. Res. 2016, 23, 24901-24911. [CrossRef] [PubMed]

101. Li, J.; Li, Q.; Li, J.; Zhou, B. Peptides derived from Rhopilema esculentum hydrolysate exhibit angiotensin converting enzyme (ACE) inhibitory and antioxidant abilities. Molecules 2014, 19, 13587-13602. [CrossRef] [PubMed]

102. Harada, K.; Maeda, T.; Hasegawa, Y.; Tokunaga, T.; Ogawa, S.; Fukuda, K.; Nagatsuka, N.; Nagao, K.; Ueno, S. Antioxidant activity of the giant jellyfish Nemopilema nomurai measured by the oxygen radical absorbance capacity and hydroxyl radical averting capacity methods. Mol. Med. Rep. 2011, 4, 919-922. [PubMed]

103. Samanta, J.K.M.P.K.; Khora, S. Antioxidant activity of fish protein hydrolysates from Sardinella longiceps. Int. J. Drug Dev. Res. 2014, 6, 137-145.

104. Chi, C.-F.; Cao, Z.-H.; Wang, B.; Hu, F.-Y.; Li, Z.-R.; Zhang, B. Antioxidant and functional properties of collagen hydrolysates from spanish mackerel skin as influenced by average molecular weight. Molecules 2014, 19, 11211-11230. [CrossRef] [PubMed]

105. Kangsanant, S.; Thongraung, C.; Jansakul, C.; Murkovic, M.; Seechamnanturakit, V. Purification and characterisation of antioxidant and nitric oxide inhibitory peptides from Tilapia (Oreochromis niloticus) protein hydrolysate. Int. J. Food Sci. Technol. 2015, 50, 660-665. [CrossRef]

106. Bardan, A.; Nizet, V.; Gallo, R.L. Antimicrobial peptides and the skin. Expert Opin. Biol. Ther. 2004, 4, 543-549. [CrossRef] [PubMed]

107. Song, R.; Wei, R.-B.; Luo, H.-Y.; Wang, D.-F. Isolation and characterization of an antibacterial peptide fraction from the pepsin hydrolysate of half-fin anchovy (Setipinna taty). Molecules 2012, 17, 2980-2991. [CrossRef] [PubMed]

108. Song, R.; Wei, R.; Zhang, B.; Wang, D. Optimization of the antibacterial activity of half-fin anchovy (Setipinna taty) hydrolysates. Food Bioprocess Technol. 2012, 5, 1979-1989. [CrossRef]

109. Ennaas, N.; Hammami, R.; Beaulieu, L.; Fliss, I. Purification and characterization of four antibacterial peptides from protamex hydrolysate of Atlantic mackerel (Scomber scombrus) by-products. Biochem. Biophys. Res. Commun. 2015, 462, 195-200. [CrossRef] [PubMed]

110. Ennaas, N.; Hammami, R.; Beaulieu, L.; Fliss, I. Production of antibacterial fraction from Atlantic mackerel (Scomber scombrus) and its processing by-products using commercial enzymes. Food Bioprod. Process. 2015, 96, 145-153. [CrossRef] 
111. Ryu, B.; Qian, Z.J.; Kim, S.K. SHP-1, A novel peptide isolated from seahorse inhibits collagen release through the suppression of collagenases 1 and 3, nitric oxide products regulated by NF-kB/p38 kinase. Peptides 2010, 31, 79-87. [CrossRef] [PubMed]

112. Ryu, B.; Qian, Z.J.; Kim, S.K. Purification of a peptide from seahorse, that inhibits TPA-induced MMP, iNOS and COX-2 expression through MAPK and NF- $\mathrm{kB}$ activation, and induces human osteoblastic and chondrocytic differentiation. Chem. Biol. Interact. 2010, 184, 413-422. [CrossRef] [PubMed]

113. Shen, Q.; Guo, R.; Dai, Z.; Zhang, Y. Investigation of enzymatic hydrolysis conditions on the properties of protein hydrolysate from fish muscle (Collichthys niveatus) and evaluation of its functional properties. J. Agric. Food Chem. 2012, 60, 5192-5198. [CrossRef] [PubMed]

114. Lødemel, J.B.; Egge-Jacobsen, W.; Olsen, R.L. Detection of TIMP-2-like protein in Atlantic cod (Gadus morhua) muscle using two-dimensional real-time reverse zymography. Biosci. Biotechnol. Biochem. 2004, 139, 253-259. [CrossRef] [PubMed]

115. Katiyar, S.; Elmets, C.A.; Katiyar, S.K. Green tea and skin cancer: Photoimmunology, angiogenesis and DNA repair. J. Nutr. Biochem. 2007, 18, 287-296. [CrossRef] [PubMed]

116. Zhuang, Y.; Hou, H.; Zhao, X.; Zhang, Z.; Li, B. Effects of collagen and collagen hydrolysate from jellyfish (Rhopilema esculentum) on mice skin photoaging induced by UV irradiation. J. Food Sci. 2009, 74, H183-H188. [CrossRef] [PubMed]

117. Diffey, B.L. Solar ultraviolet radiation effects on biological systems. Phys. Med. Biol. 1991, 36, $299-328$. [CrossRef] [PubMed]

118. Tanino, Y.; Budiyanto, A.; Ueda, M.; Nakada, A.; Nyou, W.T.; Yanagisawa, M.; Ichihashi, M.; Yamamoto, Y. Decrease of antioxidants and the formation of oxidized diacylglycerol in mouse skin caused by UV irradiation. J. Dermatol. Sci. Suppl. 2005, 1, S21-S28. [CrossRef]

119. Han, Y.-T.; Han, Z.-W.; Yu, G.-Y.; Wang, Y.-J.; Cui, R.-Y.; Wang, C.-B. Inhibitory effect of polypeptide from Chlamys farreri on ultraviolet A-induced oxidative damage on human skin fibroblasts in vitro. Pharmacol. Res. 2004, 49, 265-274. [CrossRef] [PubMed]

120. Yu, Y.; Li, Z.; Liu, X.; Wang, Y. Effects of polypeptides from Chlamys farreri on the structure of skin and the content of antioxidants in hairless mice irradiated by ultraviolet B. China J. Lepr. Skin Dis. 2004, 20, $20-23$.

121. Wang, C.-B.; Ding, B.-X.; Guo, S.-B.; Wang, Y.-Z.; Han, Y.-T.; Wang, Y.-J. Protective effect of polypeptide from Chlamys farreri on mitochondria in human dermal fibroblasts irradiated by ultraviolet B. Acta Pharmacol. Sin. 2003, 24, 692-696. [PubMed]

122. Leone, A.; Lecci, R.M.; Durante, M.; Meli, F.; Piraino, S. The bright side of gelatinous blooms: Nutraceutical value and antioxidant properties of three Mediterranean jellyfish (Scyphozoa). Mar. Drugs 2015, 13, 4654-4681. [CrossRef] [PubMed]

123. Fan, J.; Zhuang, Y.; Li, B. Effects of collagen and collagen hydrolysate from jellyfish umbrella on histological and immunity changes of mice photoaging. Nutrients 2013, 5, 223-233. [CrossRef] [PubMed]

124. Hou, H.; Li, B.; Zhang, Z.; Xue, C.; Yu, G.; Wang, J.; Bao, Y.; Bu, L.; Sun, J.; Peng, Z.; et al. Moisture absorption and retention properties, and activity in alleviating skin photodamage of collagen polypeptide from marine fish skin. Food Chem. 2012, 135, 1432-1439. [CrossRef] [PubMed]

125. Chen, T.; Hou, H. Protective effect of gelatin polypeptides from Pacific cod (Gadus macrocephalus) against UV irradiation-induced damages by inhibiting inflammation and improving transforming growth factor- $\beta$ /Smad signaling pathway. J. Photochem. Photobiol. B Biol. 2016, 162, 633-640. [CrossRef] [PubMed]

126. Shibuya, S.; Ozawa, Y.; Toda, T.; Watanabe, K.; Tometsuka, C.; Ogura, T.; Koyama, Y.I.; Shimizu, T. Collagen peptide and vitamin $\mathrm{C}$ additively attenuate age-related skin atrophy in Sod1-deficient mice. Biosci. Biotechnol. Biochem. 2014, 78, 1212-1220. [CrossRef] [PubMed]

127. Chen, T.; Hou, H.; Lu, J.; Zhang, K.; Li, B. Protective effect of gelatin and gelatin hydrolysate from salmon skin on UV irradiation-induced photoaging of mice skin. J. Ocean Univ. China 2016, 15, 711-718. [CrossRef]

128. Jimbo, N.; Kawada, C.; Nomura, Y. Optimization of dose of collagen hydrolysate to prevent UVB-irradiated skin damage. Biosci. Biotechnol. Biochem. 2016, 80, 356-359. [CrossRef] [PubMed]

129. Sun, L.; Zhang, Y.; Zhuang, Y. Antiphotoaging effect and purification of an antioxidant peptide from tilapia (Oreochromis niloticus) gelatin peptides. J. Funct. Foods 2013, 5, 154-162. [CrossRef] 
130. Zhuang, Y.; Sun, L. Preparation of reactive oxygen scavenging peptides from tilapia (Oreochromis niloticus) skin gelatin: Optimization using response surface methodology. J. Food Sci. 2011, 76, C483-C489. [CrossRef] [PubMed]

131. De Luca, C.; Mikhal'Chik, E.V.; Suprun, M.V.; Papacharalambous, M.; Truhanov, A.I.; Korkina, L.G. Skin antiageing and systemic Redox effects of supplementation with marine collagen peptides and plant-derived antioxidants: A single-blind case-control clinical study. Oxid. Med. Cell. Longev. 2016, 2016, 4389410. [CrossRef] [PubMed]

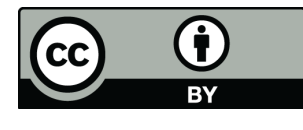

(c) 2017 by the authors. Licensee MDPI, Basel, Switzerland. This article is an open access article distributed under the terms and conditions of the Creative Commons Attribution (CC BY) license (http:/ / creativecommons.org/licenses/by/4.0/). 